REPORTS OF MORPHOLOGY
Official Journal of the Scientific Society of Anatomists,
Histologists, Embryologists and Topographic Anatomists
of Ukraine
journal homepage: https://morphology-journal.com

\title{
Morphological research of the effectiveness of perioperative local use of anesthetics and antiseptics in patients with purulent-necrotic lesions of lower extremities in diabetes mellitus
}

Babina Yu.M., Dmytriiev D.V., Nazarchuk O.A., Hormash P.P.

National Pirogov Memorial Medical University, Vinnytsia, Ukraine

\begin{tabular}{|c|c|}
\hline $\begin{array}{l}\text { ARTICLE INFO } \\
\text { Received: } 15 \text { July } 2021 \\
\text { Accepted: } 12 \text { August } 2021 \\
\text { UDC: } 611.77: 616-018: 615.28 \\
\text { CORRESPONDING AUTHOR } \\
\text { e-mail: nazarchukoa@gmail.com } \\
\text { Nazarchuk O.A. }\end{array}$ & $\begin{array}{l}\text { Ulcer-necrotic lesions of the feet are detected in 5-15\% of patients with diabetes } \\
\text { mellitus (DM). According to the literature today in Ukraine, patients with DM perform } \\
\text { high amputation of the lower extremities with diabetic foot syndrome with a frequency of } \\
19.6-42.6 \% \text {, at the same time, mortality ranges from } 8.9 \% \text { to } 25.0 \% \text {, and the total } \\
\text { mortality rate at the DM varies from } 6.6 \% \text { to } 13.5 \% \text {, often associated with the occurrence } \\
\text { of postoperative complications. The aim of the work was to study morphological indicators } \\
\text { of reparation of soft tissues of the lower extremities in patients with diabetic foot } \\
\text { syndrome on the background of local treatment during the perioperative period. We } \\
\text { investigated changes in histologic structure and character of reactions of skin tissues, } \\
\text { muscles and fascia during the period of visceral disease in patients with diabetes } \\
\text { mellitus after different types of local treatment. Then, samples of skin tissues, muscles } \\
\text { and fascia were photographed and analyzed using a light microscope OLIMPUS BX } 41 \text {. } \\
\text { In the first group of the comparison, which used standard methods of anesthesia and } \\
\text { local antiseptic povidone-iodine, granulation tissue was characterized by the complete } \\
\text { absence of fibrous structures (collagen fibers) and the presence of a small number of } \\
\text { newly formed small-diameter vessels with blistered endothelium. Vessels of young } \\
\text { granulation tissue were dilated, full-blooded, the endothelium was swollen, there was } \\
\text { significant perivascular edema. In the second group of patients (where povidone-iodine } \\
\text { and infiltration anesthesia with } 2 \% \text { lidocaine solution anesthetic was used locally) } \\
\text { there were almost no remains of necrotic tissues in the affected tissues. It should be } \\
\text { noted that there was better granulation development with fewer inflammatory-cell } \\
\text { elements, more young forms of fibroblasts and a moderate pathological vascular } \\
\text { reaction. In the first (control) group, wound healing by 3-7 days is characterized by } \\
\text { somewhat slow regeneration. Wound healing was most favorable in patients of the } \\
\text { second group, where infiltration anesthesia was used by local anesthetic and antiseptic } \\
\text { povidone-iodine. } \\
\text { Key words: diabetic foot syndrome, wound, inflammation, Povidone-iodine, Lidocaine. }\end{array}$ \\
\hline
\end{tabular}

\section{Introduction}

Purulent-necrotic lesions of the tissues of the foot in patients with diabetes mellitus (DM) are serious complications that lead to serious consequences: from high amputation of the lower extremities to the death of patients. According to European researchers, mortality after amputation below the knee in patients with diabetic foot (DF) within 1 year is $24.6 \%$, during the first 5 years $-66.3 \%$; after hip amputation, mortality during the year was noted in $43.3 \%$ of cases, five-year mortality was $83.3 \%[7,12]$. Solving the problems of mortality and disability through DF is the adoption and adherence to a strategy that includes prevention and implementation of an interdisciplinary approach to the treatment of trophic and purulent lesions of diabetic foot [11, 23, 27].

The subject of constant study and discussion are the issues of the general strategy of operative and local perioperative therapy of purulent-necrotic foci in DF $[5,11$, 23]. International experts on DF emphasize the importance of surgical treatment of chronic wounds in diabetes and active local treatment with antiseptics [4, 11, 30].

Preoperative treatment of infected foot wounds almost always requires antimicrobial therapy, which is carried out 
systemically (oral or parenteral antibiotics) and topically (by using antiseptics, antibiotics or other antimicrobials in the form of solutions, gels, ointments or dressings). The rationale for the use of topical antimicrobial therapy is to destroy or at least stop the replication of pathogenic microorganisms on the skin, mucous membranes and in the wound. Topical antimicrobials can be used as a single component or in combination with other topical or systemic antimicrobials [3, 18, 21, 22].

Topical therapy with antiseptic and antimicrobial drugs has many potential advantages over the appointment of systemic antibacterial therapy, including: high and stable concentration of antimicrobial agent in the site of infection; the need to use only a limited amount of antimicrobial agent on the affected area; prevention of potential toxicity associated with systemic treatment; ability to use new agents not available for system use; ease of use in an outpatient setting; and potentially better patient adherence to treatment. Local treatments may also be helpful in addressing the growing worldwide problem of antibiotic resistance $[4,5]$.

It is clear that the currently available literature does not provide an adequate overview of whether topical antimicrobial therapy is safe and effective in foot ulcers in people with diabetes. In addition, antimicrobial therapy does not solve all the important problems in the case of foot ulcers in patients with diabetes, namely the reduction of local pain, disruption of the normal skin microflora, insufficient penetration of the drug into intact skin and soft tissues, etc. $[8,9]$. Therefore, the morphological study of the features of the wound process is one of the main directions for solving the problem of treatment of purulent-necrotic complications of diabetic foot syndrome [25].

The aim is a comparative morphological study of the course of the wound process in purulent-necrotic lesions of the lower extremities of patients with diabetes mellitus with different approaches to local treatment in the perioperative period.

\section{Materials and methods}

The study involved 20 patients with diabetes who were hospitalized at the Vinnytsia Regional Clinical Highly Specialized Endocrinology Center of the Vinnytsia Regional Council and required surgical correction for purulent-necrotic lesions of the lower extremities. We studied changes in the histological structure and the nature of the reactions of skin, muscle and fascia tissues during the healing of an ulcer defect in patients with diabetes. Morphological and histochemical studies were performed on the first day after surgery (material for the study was removed intraoperatively), 3 days and 7 days after surgery. The study was conducted in 2020-2021 in accordance with the requirements of the Declaration of Helsinki [13]. Each study subject was provided with all the details of the medical procedures, given the opportunity to discuss any issues with the health care providers, and then signed a detailed form of informed consent for the study.
All patients were divided into 2 groups (10 patients in each group).

The first group (comparison) included patients who underwent standard anesthesia (non-narcotic analgesics) (Paracetamol, NSAIDs) and, if necessary, narcotic analgesics (Morphine), as well as local antimicrobial therapy with Povidone-iodine.

Observation group II - patients who underwent local infiltration analgesia (locally administered anesthetic $2 \%$ lidocaine $2 \mathrm{mg} / \mathrm{kg}$ ) + local antimicrobial therapy with Povidone-iodine.

During the above-mentioned terms, the patients were operatively excised ulcers and removed fragments of skin with underlying tissues from the location of the ulcer defect, departing from their edges by $0.5 \mathrm{~cm}$, as well as fragments of affected muscle tissue and fascia $1-1.5 \mathrm{~cm}$.

The test material was fixed with a $10 \%$ aqueous solution of neutral formalin for at least $48 \mathrm{~h}$, followed by washing with running water, dehydration in a system of polyhydric alcohols and pouring into paraffin according to the standard scheme. Prepared sections 7-8 $\mu \mathrm{m}$ thick were stained with hematoxylin and eosin.

Microscopy of histological specimens was performed using a light microscope OLIMPUS BX 41 (Ministry of Health of Ukraine Certificate of State Registration №8120/2008, code 9011800000) using magnifications of $x 40, x 100, x 200$ and $x 400$. Image visualization and morphometry were performed using the morphometric program Quickphoto micro 2.3 (license agreement №925113924).

Microscopy was used to assess the morphological condition and composition of skin tissues at the edges and days of the ulcer defect, the presence of pathological and reparative changes, their nature, as well as the nature of pathological changes in muscle tissue and fascia in diabetes.

The obtained data were processed statistically using the statistical application software package SPSS for Windows 10 and STATISTICA 5.5. The difference was considered significant when the $p$ values were less than 0.05 .

\section{Results}

In the study of patients of different groups, we studied the following morphometric parameters of the affected tissues in ulcerative defects of the skin, muscle tissue and fascia: the relative area of stromal edema; the relative area of the vessels of the granulation tissue; the diameter of the vessels of the granulation tissue; the number of vessels in $1 \mathrm{~mm}^{2}$; density of inflammatory-cellular infiltrate of granulation tissue (segmental leukocytes, plasma cells, macrophage elements) in $1 \mathrm{~mm}^{2}$; the number of fibroblasts in $1 \mathrm{~mm}^{2}$.

On the first day of observation, the edges and bottom of the ulcer defect were characterized by the complete absence of newly formed fibrous structures (collagen fibers). Granulation tissue was not determined at this time. In the tissues that formed the bottom and edges of the ulcer defect, 


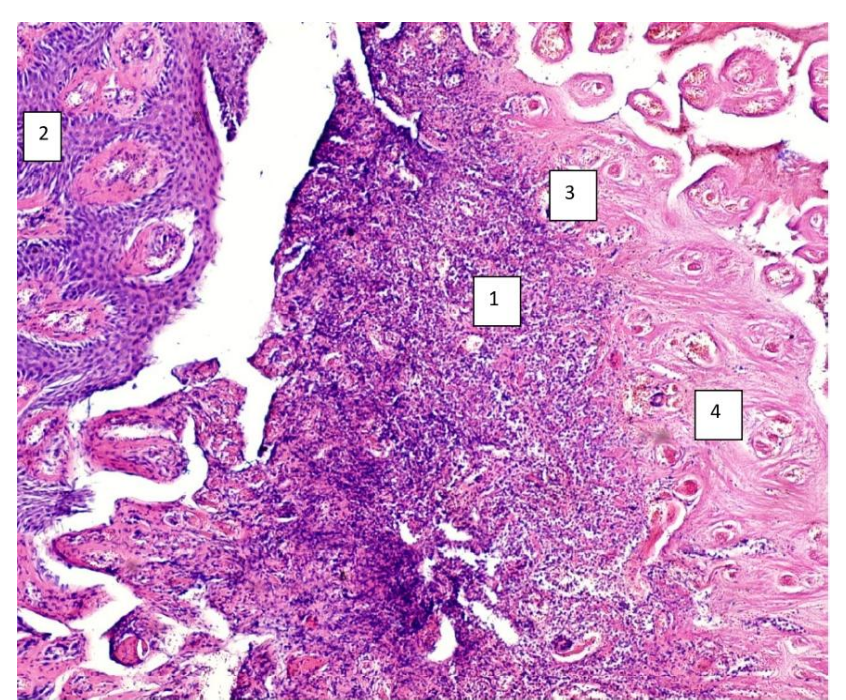

Fig. 1. The edges of the ulcer defect in the first day: diffuse inflammatory polymorphonuclear infiltration (1), pseudoepitheliomatous hyperplasia of the epidermis (2), widespread necrosis of the dermis (3) with stagnant plethora of blood vessels (4). Hematoxylin-eosin. x100.

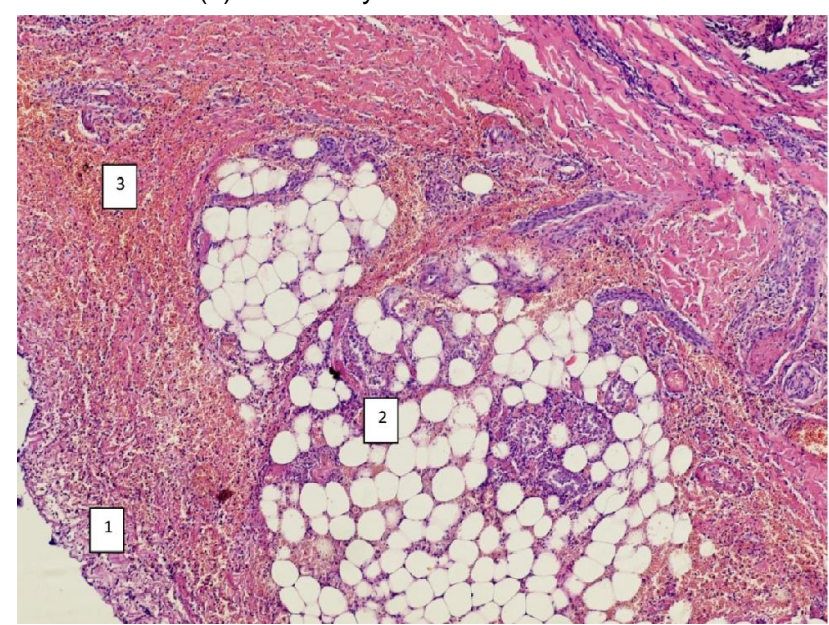

Fig. 2. The bottom of the ulcer defect on the first day before surgery: diffuse purulent-productive inflammation of the deep layers of the dermis (1) with the transition to the hypodermis (2) with widespread hemorrhage (3). Hematoxylin-eosin. x100.

common areas of necrosis and diffuse polymorphic cell infiltration were identified, which was represented mainly by segmental leukocytes. The number of segmental leukocytes was $328.2 \pm 56.3$ cells in $1 \mathrm{~mm}^{2}$. Among other cells of the inflammatory series were determined plasma cells $132.0 \pm 25.2$ in $1 \mathrm{~mm}^{2}$, cells of the lymphohistiocytic series $106.0 \pm 39.2$ in $1 \mathrm{~mm}^{2}$. The density of inflammatory cell infiltrate was $566.1 \pm 28.1$ cells in $1 \mathrm{~mm}^{2}$.

Newly formed vessels were absent during this period, which is evidence of the absence of vascular response in the affected tissue.

Young fibroblasts were also not identified. The vessels of the tissues at the edges and days of the ulcer defect were dilated, full-blooded, and some thrombosed, the wall of the vessels and their endothelium were swollen, sometimes necrotized, there was significant perivascular edema. These changes in the vessels indicated significant disturbances of microhemocirculation in the affected tissues.

Thus, in the studied samples were determined the remains of necrotic tissues, the absence of granulations, a large number of inflammatory cell elements, a pronounced pathological vascular reaction, morphometric parameters did not differ by groups $(p<0,05)$ (Fig. 1, 2).

On the third day of observation in patients of group I (comparison group) granulation tissue was characterized by the complete absence of fibrous structures (collagen fibers) and the presence of a small number of newly formed vessels of small caliber with swollen endothelium. The relative area of the vascular bed of granulation tissue was $12.68 \pm 2.80 \%$, and their average diameter was $16.14 \pm$ $1.62 \mu \mathrm{m}$. The relative area of stromal edema was $25.12 \pm 3.41 \%$, which is evidence of vascular response and increased permeability of their wall in the affected tissue.

Various forms of inflammatory-cellular elements of granulation tissue (segmental leukocytes, plasma cells, macrophage cells) were determined in the amorphous intermediate. The number of segmental leukocytes was $304,2 \pm 25,3$ cells in $1 \mathrm{~mm}^{2}$, plasma cells $-122,0 \pm 40,3$ in 1 $\mathrm{mm}^{2}$, lymphohistiocytic elements - 86,70 $\pm 12,60$ in $1 \mathrm{~mm}^{2}$. The density of inflammatory cell infiltrate was $512,2 \pm 58,7$ cells in $1 \mathrm{~mm}^{2}$. At this time, young fibroblasts were also not identified.

The vessels of the young granulation tissue were dilated, full-blooded, the endothelium was swollen, there was significant perivascular edema. Sludge phenomenon of erythrocytes was observed in some vessels. These changes in the vessels indicated significant violations of microhemocirculation in the affected tissues (Fig. 3).

In the second group of observations on the third day we

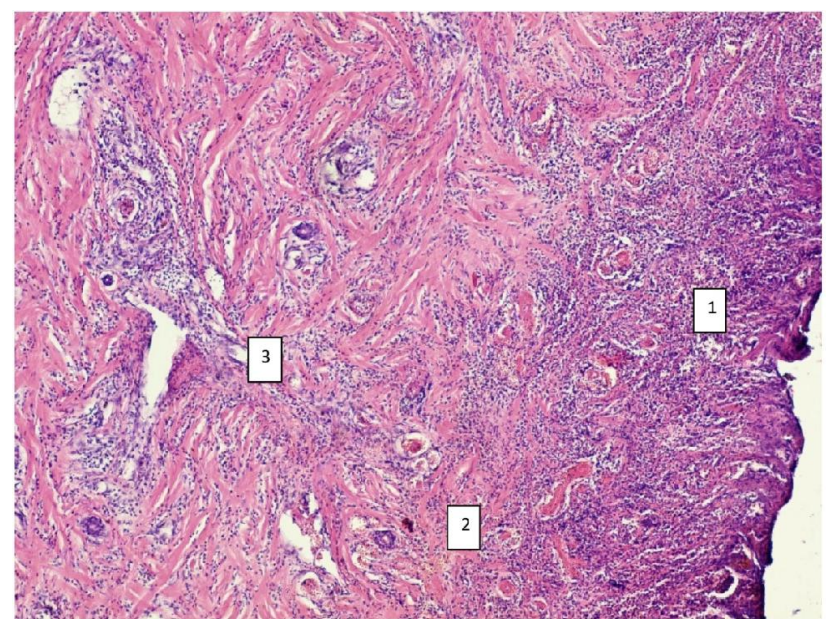

Fig. 3. The area of skin with an ulcer defect three days after treatment, group I of patients. Significant infiltration of segmental neutrophilic leukocytes of the dermis at the edges of the ulcer defect with the presence of lymphocytes (1), stagnant plethora of vessels with erythostasis (2), moderate edema of the fibrous tissue of the dermis (3). Hematoxylin-eosin. x100. 


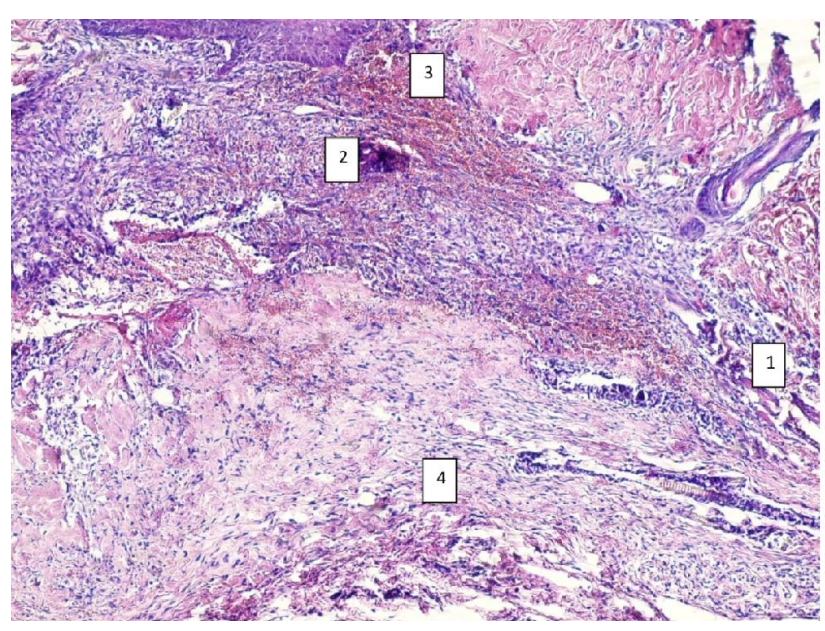

Fig. 4. An area of skin with an ulcer defect three days after surgery. Group II. Layer of necrotized tissues (1), diffuse polymorphonuclear infiltration in the surface layers of the dermis (2), epidermis on the edge of the ulcer defect (3), edema, diffuse inflammatory cell infiltration in the deep layers of the dermis (4). Hematoxylin-eosin. x100.

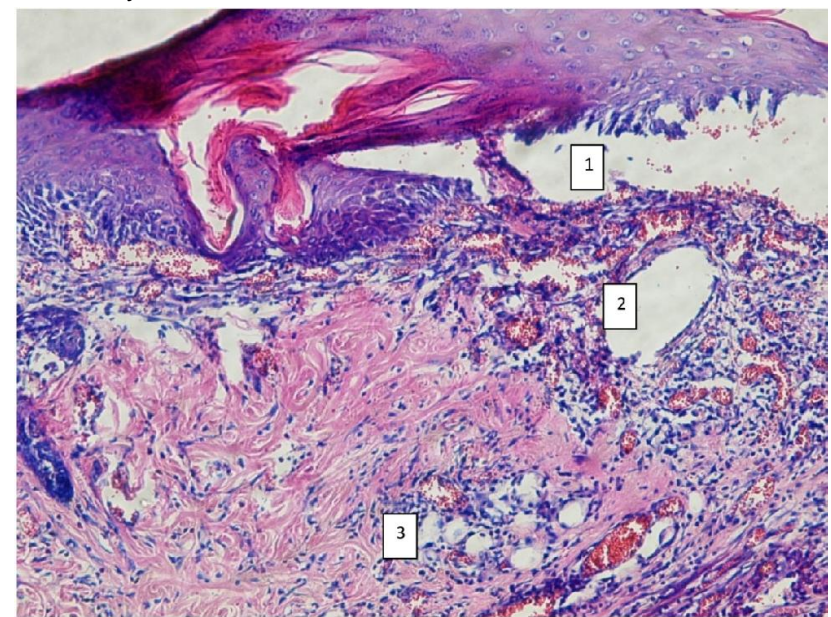

Fig. 5. Bottom, edges of the ulcer defect on the 7th day after surgery. Group I. Proliferation of the epithelium (1) at the edges of the ulcer defect, granulation tissue rich in blood vessels, with inflammation (2), in the deep layers of the granulation tissue is replaced by young scar (3). Hematoxylin-eosin x100.

determined a slightly better dynamics of morphometric parameters. During this period, granulation tissue was also characterized by almost complete absence of fibrous structures, its main substance was also represented by amorphous unstructured eosinophilic substance, but it identified a much smaller number of inflammatory cells, more macrophage elements - precursors of young forms of fibroblasts, recorded the appearance. Large, capillary-type, moderately full-blooded vessels of granulations were determined in a larger number. Signs of erythrostasis and sludge phenomenon were almost not determined (Fig. 4). The number of segmental leukocytes was $262.9 \pm 23.6$ cells in $1 \mathrm{~mm}^{2}$, plasma cells $-103.2 \pm 11.2$ in $1 \mathrm{~mm}^{2}$, lymphohistiocytic elements $-70.41 \pm 5.67$ in $1 \mathrm{~mm}^{2}$. The density of inflammatory cell infiltrate was $435.9 \pm 34.7$ cells in $1 \mathrm{~mm}^{2}$. Young fibroblasts were in the amount of $12.00 \pm 2.67$ cells in $1 \mathrm{~mm}^{2}$.

The relative area of the vascular bed of the granulation tissue was $9.620 \pm 1.900 \%$, and their average diameter was $19.32 \pm 2.70 \mu \mathrm{m}$. These changes in the vessels indicated moderate disturbances of microhemocirculation in the affected tissues.

The relative area of stromal edema was $21.28 \pm 1.34 \%$, which is evidence of a moderate vascular response and increased permeability of their wall in the affected tissue.

On the seventh day of observation in patients of comparison group (group I) there were signs of incomplete inflammatory changes with completely unformed full-fledged cicatricial fibrous tissue with a large number of fibrocytes and collagen fibers, reduced slit-like non-functioning vessels. Patients in the comparison group had inflammatorycell infiltration for 7 days - segmental leukocytes were $125,8 \pm 12,5$ cells in $1 \mathrm{~mm}^{2}$, there was a significant number of lymphohistiocytic elements - 52,31 $\pm 3,89$ in $1 \mathrm{~mm}^{2}$, a significant number of young forms of fibroblasts $-24,41 \pm 1,60$ in $1 \mathrm{~mm}^{2}$. The density of the inflammatory cell infiltrate was $284,8 \pm 12,5$ cells in $1 \mathrm{~mm}^{2}$. Stromal edema and other signs of pathological vascular reaction were mild. The diameter of the granulation vessels was $13,16 \pm 5,80 \mu \mathrm{m}$, their relative area was $10,06 \pm 2,50 \%$. The relative area of perivascular and stromal edema was $22,42 \pm 5,80 \%$. Part of the vessels was in a state of reduction (Fig. 5).

On the seventh day of observation in patients of the second group of comparison there was no complete resolution of inflammatory changes with the formation of full-fledged scar coarse fibrous tissue with a large number of fibrocytes and collagen fibers, reduced slit-like nonfunctioning vessels. At the same time, there was a decrease

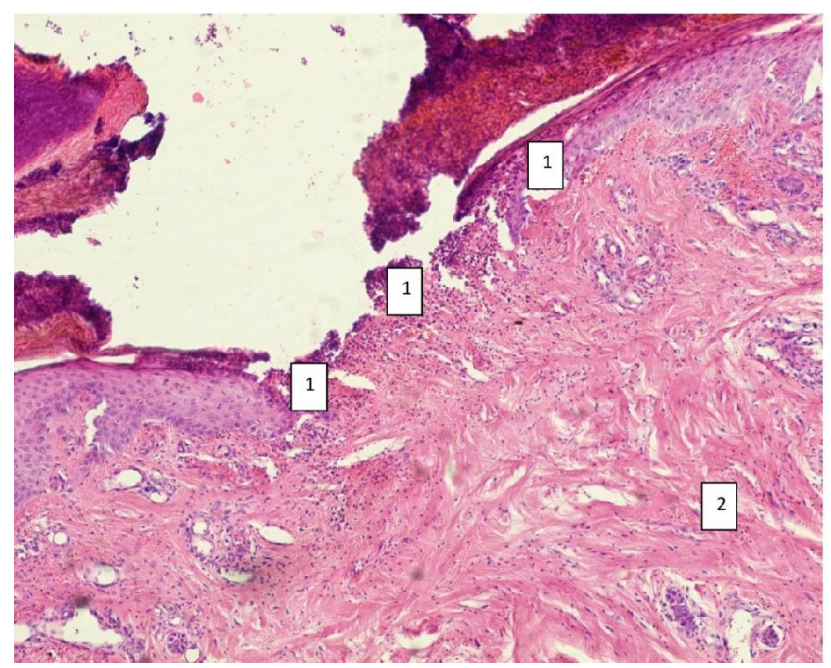

Fig. 6. Bottom, edges of the ulcer defect on the 7th day after surgery, group II. The growth of the epidermis in a layer on the young granulation tissue (1), the granulation tissue is replaced by scar fibrous tissue, which is sometimes determined by a slight infiltration of lymphohistiocytic elements (2). Hematoxylin-eosin. $\mathrm{x} 100$. 
in the dynamics of signs of inflammatory cell infiltration segmental leukocytes did not exceed $104,5 \pm 12,6$ cells in 1 $\mathrm{mm}^{2}$, there was an increase in lymphohistiocytic elements - 92,50 $\pm 3,78$ in $1 \mathrm{~mm}^{2}$, recorded a significant number of young forms of fibroblasts - 42,00 $\pm 4,60$ in $1 \mathrm{~mm}^{2}$. The density of the inflammatory cell infiltrate was $274,8 \pm 23,8$ cells per 1 $\mathrm{mm}^{2}$. Stromal edema and other pathological vascular reactions were less pronounced. The diameter of the vessels of the granulations was $212,0 \pm 5,4 \mu \mathrm{m}$, their relative area was $9,620 \pm 1,450 \%$. The relative area of perivascular and stromal edema was $22,42 \pm 2,50 \%$. Histologically, part of the vessels was in a state of reduction (Fig. 6).

\section{Discussion}

This study compared the morphological parameters of skin fragments during ulcer excision and at the stage of ulcer healing after different methods of local treatment. Thus, on the first day of the experiment in all studied samples determined the remains of necrotic tissues, lack of granulation, a large number of inflammatory cell elements, a pronounced pathological vascular reaction, morphometric parameters did not differ by groups $(p<0,05)$ (Fig. 1, 2).

On day 3 of the experiment in the first comparison group, which used standard methods of analgesia and topical antiseptic povidone-iodine, granulation tissue was characterized by complete absence of fibrous structures (collagen fibers) and the presence of a small number of newly formed small vessels with swollen endothelium. The vessels of the young granulation tissue were dilated, fullblooded, the endothelium was swollen, there was significant perivascular edema. Sludge phenomenon of erythrocytes was observed in some vessels. These changes in the vessels indicated significant disturbances of microhemocirculation in the affected tissues.

In group II of patients (where povidone-iodine and infiltration anesthesia with anesthetic $2 \%$ lidocaine solution were used topically) there were almost no residues of necrotic tissue in the affected tissues, there was a better development of granulations with fewer inflammatory cell elements, more young forms of fibroblasts, moderate pathological vascular reaction was observed (Fig. 4).

On day 7 of the study, the best ulcer healing rates were in group 2, where infiltration anesthesia with a local anesthetic was used prior to local antiseptic therapy. Thus, in patients of comparison group (group I) there were signs of incomplete inflammatory changes with completely unformed full-fledged cicatricial fibrous tissue with a large number of fibrocytes and collagen fibers, reduced slit-like nonfunctioning vessels. Patients of the second comparison group also did not yet fully resolve inflammatory changes with the formation of full-fledged scar coarse fibrous tissue with a large number of fibrocytes and collagen fibers, reduced slit-like dysfunctional vessels, while a decrease in the dynamics of inflammatory cell signs was found.

One of the main components of effective treatment of trophic ulcers is adequate wound disinfection [29]. In this experiment, we studied the antiseptic povidone-iodine. According to domestic and foreign in vitro studies, povidoneiodine has a broad spectrum of action against gram-positive (including methicillin-resistant Staphylococcus aureus [MRSA]) and gram-negative bacteria, fungi, viruses, protozoa and bacterial spores [8, 21, 22].

Another serious problem for effective healing of trophic ulcers today is the formation of bacterial biofilms, which lead to resistance of microorganisms to antibacterial therapy and slow down the wound healing process $[14,19]$, especially for chronic ulcers.

That is why the great advantage of povidone-iodine drugs is their high efficiency even in the presence of biofilms, which has been proven in a number of studies [8, 9, 14]. Thus, studies have shown that povidone-iodine exhibits antibacterial activity, especially against Pseudomonas and S.aureus species, which predominate in biofilms, and improve healing [6]. Povidone-iodine has many characteristics that confirm its place in the treatment of epithelial injuries. It has a prooxidant effect on healing [9, $10]$, is better tolerated than silver sulfadiazine or chlorhexidine, on histological evaluation of wound healing [2, 3] and enhances angiogenesis [5]. It also supports healing through a pronounced anti-inflammatory effect on cytokines, T lymphocytes and macrophages [10, 15]. Povidone-iodine can also inhibit excessive protease levels in chronic non-healing wounds. Some in vitro data indicate that $10 \%$ of povidone-iodine is toxic to cells involved in wound repair, such as fibroblasts and keratinocytes [14, 28]; however, these data have not been clinically proven [1].

According to our morphological data, the best result of local treatment of trophic ulcers was after the use of infiltration anesthesia with $2 \%$ lidocaine. Thus, according to international and domestic data, it is currently good practice to infiltrate local anesthetics along the incision to prevent postoperative pain. This can reduce the use of opioids and the side effects they cause. However, local anesthetics have, in addition to the main analgesic effect, also antimicrobial and anti-inflammatory action [15, 16, 19]. The antimicrobial action of local anesthetics has been described in the in vitro literature and in experimental studies. In experimental studies, it was reported that $1-3 \%$ lidocaine had antimicrobial activity on $\mathrm{S}$. aureus $[20,24,26]$.

A comprehensive literature search using MEDLINE 1950 - for in vitro and in vivo studies on the antimicrobial activity of various local anesthetics in a wide range of bacterial and fungal pathogens $[16,19]$. According to various studies, local anesthetics (as a class) have antimicrobial properties against a wide range of human pathogens. Several local anesthetics at concentrations commonly used in clinical settings (eg, bupivacaine $0.125-0.75 \%$; lidocaine 1-3\%) inhibit the growth of numerous bacteria and fungi under different conditions. Different local anesthetics showed different degrees of antimicrobial ability; bupivacaine and lidocaine, for example, inhibit growth to a much greater extent than ropivacaine. Higher concentrations, longer exposure 
and higher temperatures correlate with a proportional increase in microbial growth inhibition. Limited studies attribute the mechanism of action of antimicrobial activity of local anesthetics to the violation of the permeability of microbial cell membranes, which leads to leakage of cellular components and subsequent lysis of cells. In this capacity, local anesthetics can be considered as an adjunct to traditional antimicrobial use in clinical or laboratory settings [19].

Further study of local anesthetics as antimicrobials, in monotherapy and in combination with antiseptics in the laboratory and in the clinic in order to develop alternative methods for the prevention and treatment of infectious perioperative complications in surgery seems promising.

\section{Conclusions}

1. Healing of postoperative wounds in patients with diabetic foot ulcers using various methods of postoperative local treatment occurs through a natural wound process with the presence of mandatory stages: damage, inflammation and regeneration.

2. The use of various methods of perioperative analgesia and local antimicrobial treatment affects the second stage of healing - inflammation.

3. When using standard anesthesia and local

\section{References}

[1] Amin, N., \& Doupis, J. (2016). Diabetic foot disease: From the evaluation of the "foot at risk" to the novel diabetic ulcer treatment modalities. World Journal of Diabetes, 7(7), 153164. https://doi.org/10.4239/wjd.v7.i7.153

[2] Antonyuk-Kysil, V.M., Kucheruk, E.F., Nevmerzhitsky, A.S., \& Les, V.M. (2016). Можливості хірургічного лікування трофічних виразок венозного генезу нижніх кінцівок у пацієнтів похилого і старечого віку в амбулаторних умоBax [Possibilities of surgical treatment of trophic ulcers of venous origin of the lower extremities in elderly and senile patients in an outpatient setting]. Вісник наукових досліджень - Bulletin of scientific research, (3), 46-50.

[3] Babina, Y.M., Dmitriev, D.V., \& Nazarchuk, O.A. (2019). Антимікробна активність локальних анальгетиків проти збудників ранової інфекції, пов'язаної з наданням медичної допомоги [Antimicrobial activity of local analgesics against pathogens of wound infection associated with medical care]. Медицина невідкладних станів - Emergency medicine, (2), 162.

[4] Bondarenko, O.N., Galstyan, G.R., \& Dedov, I.I. (2015). Ocoбенности клинического течения критической ишемии нижних конечностей и роль эндоваскулярной реваскуляризации у больных сахарным диабетом [Features of the clinical course of critical lower limb ischemia and the role of endovascular revascularization in patients with diabetes mellitus]. Сахарный диабет - Diabetes Mellitus, 18(3), 5769. doi: 10.14341/DM2015357-69

[5] Braun, L.R., Fisk, W.A., Lev-Tov, H., Kirsner, R.S., \& Isseroff, R.R. (2014). Diabetic foot ulcer: An evidence-based treatment update. Am. J. Clin. Dermatol., 15, 267-281. doi: 10.1007/ s40257-014-0081-9

[6] Cooper, R.A., (2007). lodine revisited. Int. Wound J., 4(2), 124137. doi: 10.1111/j.1742-481X.2007.00314.x. antimicrobial therapy with the antiseptic drug povidone-iodine in the postoperative period, wound healing for 3-7 days was characterized by somewhat delayed regeneration.

4. Wound healing was most favorable in patients of the second group, where infiltration anesthesia with a local anesthetic was used.

5. Local anesthetics are used to control pain in the postoperative period, and, in particular, are used to anesthetize the wound in the acute period and to reduce stress when changing bandages. However, given their antimicrobial properties and the current state of antibiotic resistance in Ukraine and the world at large, these observations suggest that the surgical benefits of local anesthesia may go beyond its analgesic properties and may play an antimicrobial role in the prevention and treatment of surgical wound infection.

6. The obtained morphological data suggest the need for further research to study the effectiveness of local use of local anesthetics in the wound, which will be safer, increase patient comfort and safety, reduce consumption of opioid analgesics after surgery and their toxic effects, will not increase the risk of infection and will not interfere with wound healing processes, as well as reduce the length of hospital stay of patients with purulent-necrotic ulcers of the lower extremities.

[7] Conte, M.S., Bradbury, A.W., Kolh, P., White, J.V., Dick, F., Fitridge, R. ... Murad, M.H. (2019). Global vascular guidelines on the management of chronic limb-threatening ischemia. GVG Writing Group J. Vasc. Surg., 69(6S), 3-125. doi: 10.1016/ j.jvs.2019.02.016

[8] Drosou, A., Falabella, A., \& Kirsner, R.S. (2003). Antiseptics on wounds: an area of controversy. Wounds, 15, 149-166.

[9] Dumville, J.C., Lipsky, B.A., Hoey, C., Cruciani, M., Fiscon, M., \& Xia, J. (2017). Topical antimicrobial agents for treating foot ulcers in people with diabetes. Cochrane Database Syst. Rev., 6(6), 110-138. doi:10.1002/14651858.CD011038.pub2

[10] Galkowska, H., Wojewodzka, U., \& Olszewski, W.L. (2006). Chemokines, cytokines, and growth factors in keratinocytes and dermal endothelial cells in the margin of chronic diabetic foot ulcers. Wound Repair Regen., 14(5), 558-565. doi: 10.1111/j.1743-6109.2006.00155.x

[11] Graziani, L., \& Piaggesi, A. (2010). Indications and clinical outcomes for below knee endovascular therapy: Review article. Catheter Cardiovasc. Interv., 75, 433-443. doi: 10.1002/ ccd. 22287

[12] Gök, Ü., Selek, Ö., Selek, A., Güdük, A., \& Güner, M.Ç. (2016). Survival evaluation of the patients with diabetic major lowerextremity amputations. Musculoskelet Surg., 100, 145-148. doi: 10.1007/s12306-016-0399-y

[13] Helsinki Declaration of the World Medical Association "Ethical principles of medical research with human participation as an object of study": adopted by the 18th General Assembly of the Military Medical Academy, Helsinki, Finland. (1964). Ed.: from 01.10.2008 [Electronic resource]. Legislation of Ukraine. Available: http://zakon5.rada.gov.ua/laws/show/990_005

[14] Hoekstra, M.J., Westgate, S.J., \& Mueller, S. (2017). Povidoneiodine ointment demonstrates in vitro efficacy against biofilm formation. Int. Wound J., 14(1), 172-179. doi: 10.1111/iwj.12578 
[15] Hoogeveen, R.C., Dorresteijn, J.A.N., Kriegsman, D.M.W., \& Valk, G.D. (2015). Complex interventions for preventing diabetic foot ulceration. Cochrane Database of Systematic Reviews, 8. Art. No.: CD007610. doi: 10.1002/14651858.CD007610.pub3

[16] Johnson, S.M., Saint John, B.E., \& Dine, A.P. (2008). Local anesthetics as antimicrobial agents: a review. Surgical Infections, 9(2), 205-213. doi: 10.1089/sur.2007.036

[17] Korejba, K.A., Minabutdinov, A.R., Tueshev, L.M., Nuretdinov, A.R., \& Lukin, P.S. (2019). Синдром диабетической стопы. Стационарзамещающая методика на основе fast track-хирургии [Diabetic foot syndrome. Replacement for inpatient treatment technique based on the fast track surgery]. Амбулаторная хирургия - Ambulatory Surgery, (1-2), 72-79. https:// doi.org/10.21518/1995-1477-2019-1-2-72-79

[18] Kovalchuk, V.P. (2006). Характеристика арсеналу антисептичних засобів, зареєстрованих в Україні [Characteristics of the arsenal of antiseptic agents registered in Ukraine]. Biomedical and Biosocial Anthropology, 6, 71-76.

[19] Lu, C.W., Lin, T.Y., Shieh, J.S, Wang, M.J., \& Chiu, K.M. (2014). Antimicrobial effect of continuous lidocaine infusion in a Staphylococcus aureus-induced wound infection in a mouse model. Ann. Plast. Surg., 73(5), 598-601. doi: https://doi.org/ 10.17085/apm.2019.14.2.165

[20] Maillard, J.Y., Kampf, G., \& Cooper, R. (2021). Antimicrobial stewardship of antiseptics that are pertinent to wounds: the need for a united approach. JAC - Antimicrob. Resist., 3(1), dlab027. doi: 10.1093/jacamr/dlab027

[21] Nazarchuk, O.A. (2016). Антисептики: сучасна стратегія боротьби зі збудниками інфеекційних ускладнень [Antiseptics: the current strategy of fighting against infectious diseases]. Клінічна хірургія - Clinical Surgery, 9, 59-61.

[22] Nazarchuk, O.A. (2019). Дослідження протимікробної ефрективності сучасних антисептичних засобів на основі декаметоксину та повідону йоду [Research of antimicrobial efficacy of modern antiseptic agents based on decamethoxine and povidone-iodine]. Периопераційна медицина Perioperative Medicine, 2(1), 4-10. doi: 10.31636/prmd.v2i1.1

[23] Paisley, A.N., Kalavalapalli, S., Subudhi, C.P., Chadwick, P.R., Chadwick, P.J., \& Young, B. (2012). Real time presence of a microbiologist in a multidisciplinary diabetes foot clinic. Diabetes Res. Clin. Pract., 96(1), 1-3. doi: 10.1016/j.diabres.2011.11.024

[24] Parr, A.M., Zoutman, D.E., \& Davidson, J.S. (1999). Antimicrobial activity of lidocaine against bacteria associated with nosocomial wound infection. Ann. Plast. Surg., 43(3), 239-245. doi: 10.1097/ 00000637-199909000-00003

[25] Proshin, A.V. (2010). Морфологическая характеристика раневого процесса у больных с гнойно-некротическими формами поражений нижних конечностей при сахарном диабете [Morphological characteristics of the wound process in patients with purulent-necrotic forms of lower limb lesions in diabetes mellitus]. Вестник Новгородского государственного университета имени Ярослава Мудрого - Bulletin of the Novgorod State University named after Yaroslav Mudryy, (59), 63-66.

[26] Stratford, A.F., Zoutman, D.E., \& Davidson, J.S. (2002). Effect of Lidocaine and Epinephrine on Staphylococcus aureusin a Guinea pig model of surgical wound infection. Plast. Reconstr. Surg., 110, 1275-1279. doi: 10.1097/01.PRS.0000025427.86301.8A

[27] Uccioli, L., Meloni, M., Izzo, V., Giurato, L., Merolla, S., \& Gandini, R. (2018). Critical limb ischemia: current challenges and future prospects. Vasc. Health Risk Manag., 26(14), 63-74. doi: 10.2147/VHRM.S125065

[28] Vermeulen, H., Westerbos, S.J., \& Ubbink, D.T. (2010). Benefit and harm of iodine in wound care: a systematic review. J. Hosp. Infect., 76(3), 191-199. doi: 10.1016/j.jhin.2010.04.026.

[29] Vuorisalo, S., Venermo, M., \& Lepäntalo, M. (2009). Treatment of diabetic foot ulcers. J. Cardiovasc. Surg. (Torino), 50(3), 275-291. PMID: 19543189.

[30] Zaitseva, E.L., Doronina, L.P., Molchkov, R.V., Voronkova, I.A., Mitish, V.A., \& Tokmakova, A.lu. (2014). Особенности репарации тканей у пациентов с нейропатической и нейроишемической формами синдрома диабетической стопы на фоне терапии отрицательным давлением [Features of angenesis against the background of negative pressure wound therapy in patients with neuropathic and neuroischemic forms of diabetic foot ulcers]. Вестник хирургии имени И.И.Грекова - Herald of Surgery named after I.I.Grekov, 173(5), 64-72. PMID: 25823338

\section{МОРФОЛОГІЧНЕ ДОСЛІДЖЕННЯ ЕФЕКТИВНОСТІ ПЕРІОПЕРАЦІЙНОГО ЛОКАЛЬНОГО ЗАСТОСУВАННЯ АНЕСТЕТИКІВ ТА} АНТИСЕПТИКІВ У ХВОРИХ З ГНІЙНО-НЕКРОТИЧНИМИ УРАЖЕННЯМИ НИЖНІХ КІНЦІВОК ПРИ ЦУКРОВОМУ ДІАБЕТІ Бабіна Ю.М., Дмитрієе Д.В., Назарчук О.А., Гормаш П.П.

Виразково-некротичні ураження стоп виявляють у 5-15\% хворих на иукровий діабет (ЦД). Згідно даних літератури сьогодні в Україні у хворих на ЦД виконують високу ампутацію нижніх кінцівок при синдромі діабетичної стопи з частотою 19,642,6\%, при цьому летальність складає від 8,9\% до 25,0\%, а загальна смертність при ЦД варіює від 6,6\% до 13,5\%, що часто пов'язують з виникненням післяопераційних ускладнень. Метою роботи стало вивчення морфологічних показників репарації м'яких тканин нижніх кінцівок у пацієнтів із синдромом діабетичної стопи на фооні місцевого лікування у періопераційному періоді. Досліджували зміни гістологічної структури та характер реакцій тканин шкіри, м'язів та фрасцій під час загоєння виразки у хворих на цукровий діабет після різних видів місцевого лікування. Потім зразки тканин шкіри, м'язів та фрасцій фотографували та аналізували зображення за допомогою світлового мікроскопа OLIMPUS BX 41. У першій групі порівняння, яка використовувала стандартні методи анестезії та місцево антисептичний повідон-йод, грануляційна тканина характеризувалась повною відсутністю волокнистих структур (колагенових волокон) та наявністю невеликої кількості новоутворених судин малого діаметра з набряклим ендотелієм. Судини молодої грануляційної тканини були дилятовані, повнокровні, ендотелій був набряклий, мав місце значний периваскулярний набряк. У II групі хворих (де місцево використовували повідон-йод та інфрільтраційну анестезію анестетиком 2\% розчину лідокаїну) в уражених тканинах майже не було залишків некротичних тканин. Слід відмітити, що мав місце кращий розвиток грануляцій з меншою кількістю запально-клітинних елементів, більшою кількістю молодих форм фрібробластів та помірною патологічною судинною реакцією. У першій (контрольній) групі загоєння ран на 3-7 добу характеризується дещо повільною регенерацією. Таким чином, загоювання ран було найбільш сприятливим у пацієнтів другої групи, де місцево використовували повідон-йод та інфрільтраційну анестезію анестетиком 2\% розчину лідокаїну.

Ключові слова: синдром діабетичної стопи, рана, запалення, повідон-йод, лідокаїн. 